$110 / 231958 \% 0$

SANDIA REPORT

1 SAND95-8009 • UC-402

Unlimited Release

Printed September 1995

\title{
Pollution Prevention Opportunity Assessment for Technical Art
}

H. M. Torres

Prepared by

Sandia National Laboratories

Albuquerque, New Mexico 87185 and Livermore, California 9455

for the United States Department of Energy

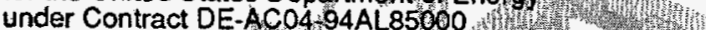

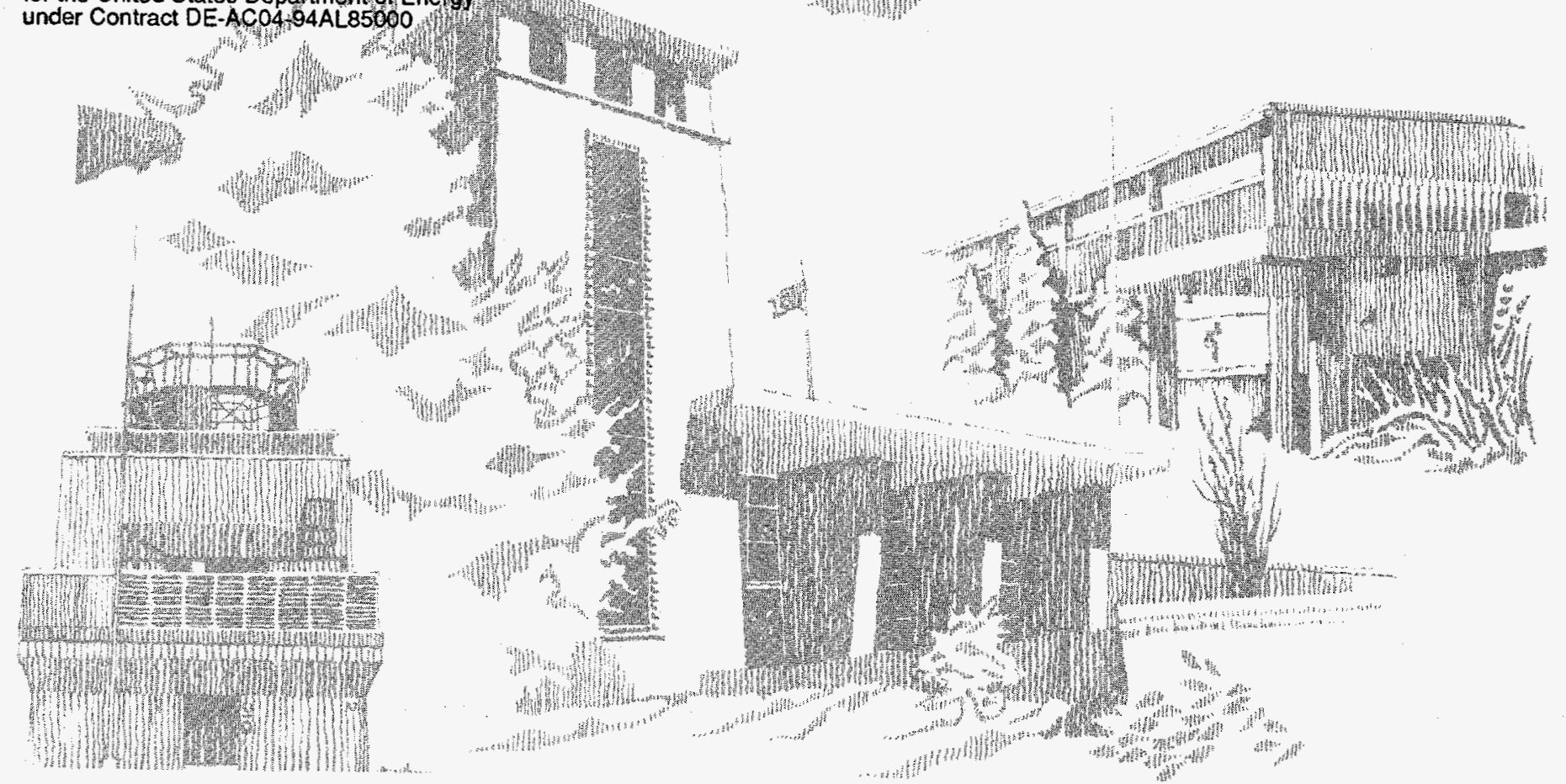


Issued by Sandia National Laboratories, operated for the United States Department of Energy by Sandia Corporation.

NOTICE: This report was prepared as an account of work sponsored by an agency of the United States Government. Neither the United States Government nor any agency thereof, nor any of their employees, nor any of the contractors, subcontractors, or their employees, makes any warranty, express or implied, or assumes any legal liability or responsibility for the accuracy, completeness, or usefulness of any information, apparatus, product, or process disclosed, or represents that its use would not infringe privately owned rights. Reference herein to any specific commercial product, process, or service by trade name, trademark, manufacturer, or otherwise, does not necessarily constitute or imply its endorsement, recommendation, or favoring by the United States Government, any agency thereof or any of their contractors or subconractors. The views and opinions expressed herein do not necessarily state or reflect those of the United States Government, any agency thereof or any of their contractors or subcontractors.

This report has been reproduced from the best available copy.

Available to DOE and DOE contractors from:

Office of Scientific and Technical Information

P. O. Box 62

Oak Ridge, TN 37831

Prices available from (615) 576-8401, FTS 626-8401

Available to the public from:

National Technical Information Service

U.S. Department of Commerce

5285 Port Royal Rd.

Springfield, VA 22161 
UC-402

SAND95-8009

Unlimited Release

Printed September 1995

\title{
POLLUTION PREVENTION OPPORTUNITY ASSESSMENT FOR TECHNICAL ART
}

\author{
Hilary M. Torres \\ Sandia National Laboratories/California
}

\begin{abstract}
This pollution prevention opportunity assessment was conducted to evaluate Technical Art, which is located in Building 912, Room 138. This assessment documents the processes, identifies the hazardous chemical waste streams generated by these processes, and recommends possible ways to minimize waste.
\end{abstract}

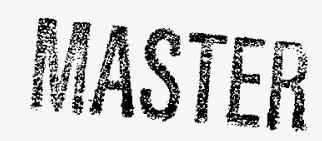

DISTRIBUTION OF THIS DOCUMENT IS UNLIMITED

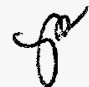




\section{DISCLAIMER}

Portions of this document may be illegible in electronic image products. Images are produced from the best available original document. 


\section{CONTENTS}

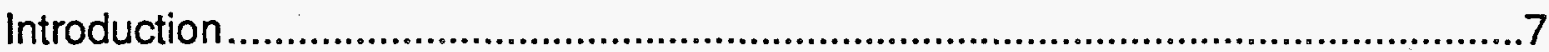

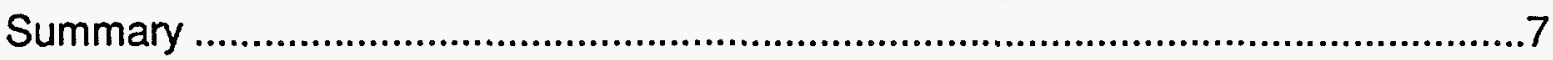

Pollution Prevention Opportunity Assessment ..................................................

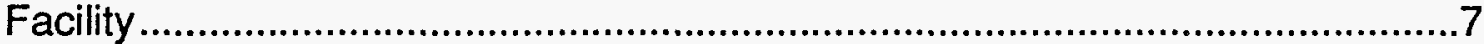

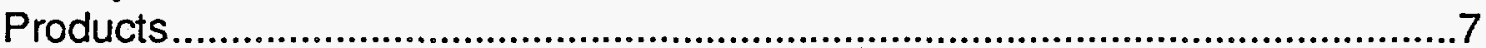

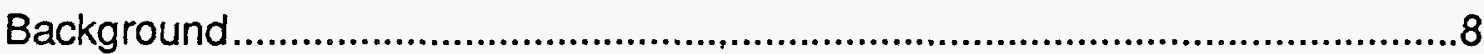

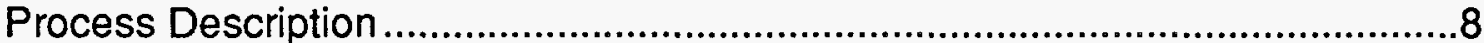

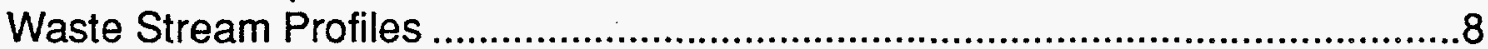

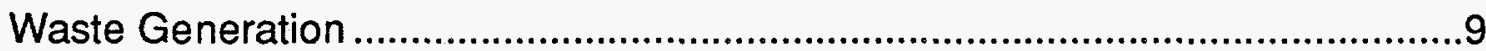

Waste Minimization Recommendations .....................................................10

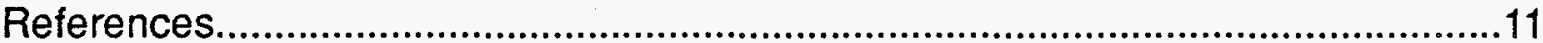

\section{ILLUSTRATIONS AND TABLES}

No.

Fig. 1 Technical Art Floor Plan and Equipment Layout, Bldg. 912/Rm. 138 ........8

Fig. 2 Process Flow Diagram of the Agfa Rapiline 43 Processor .......................9

Fig. 3 Waste Generation Summary (1993-94) ............................................. 10

Table 1 Agfa Rapiline 43 Working Bath Chemistry ...........................................9

Table 2 Hazardous Waste Generation Summary (1993-94) ................................9 


\section{POLLUTION PREVENTION OPPORTUNITY ASSESSMENT FOR TECHNICAL ART}

\section{Introduction}

Department of Energy (DOE) orders 5400.1 and 5400.3 mandate the development of a waste minimization program.1,2 The program's goals are to:

- reduce volumes of hazardous wastes and toxicity,

- implement a system of tracking and reporting improvements, and

- devise a method for performing tasks.

To satisfy the requirements of this program, Sandia conducts pollution prevention opportunity assessments (PPOAs) to identify waste-generating processes. The information collected from a PPOA then is used to identify waste minimization opportunities.

This PPOA was conducted on Technical Art, which is part of the Technical Communications Department, according to the Pollution Prevention Opportunity Assessment Plan for SNL/California. ${ }^{3}$ The primary purpose of this PPOA is to document waste-generating processes, identify the waste streams, and serve as a reference for future assessments. It will be reevaluated in approximately 18 to 24 months.

\section{Summary}

Technical Art (Tech Art) is part of the Technical Communications Department (Org. 8535). Tech Art provides the following services: computer-generated two-dimensional and threedimensional imagery, graphic design, viewgraphs, figures and graphs for reports, and desk top publishing. As computer technology has advanced, Tech Art has replaced manual processes with computer processes.

The majority of hazardous waste is generated by an Agfa Rapiline 43 processor. The major waste streams comprise spent fixer and developer. Tech Art personnel have already implemented waste minimization procedures, and no further recommendations were made.

\section{Pollution Prevention Opportunity Assessment}

\section{Facility}

Technical Art is located in Building 912, Room 138 (see Fig. 1). This area comprises offices, storage closets, a room for the Agfa Rapiline 43 processor, a vault, and another, larger work room. The work room is used for a spray booth, a work bench used for layout and cutting, and storage of art materials. 


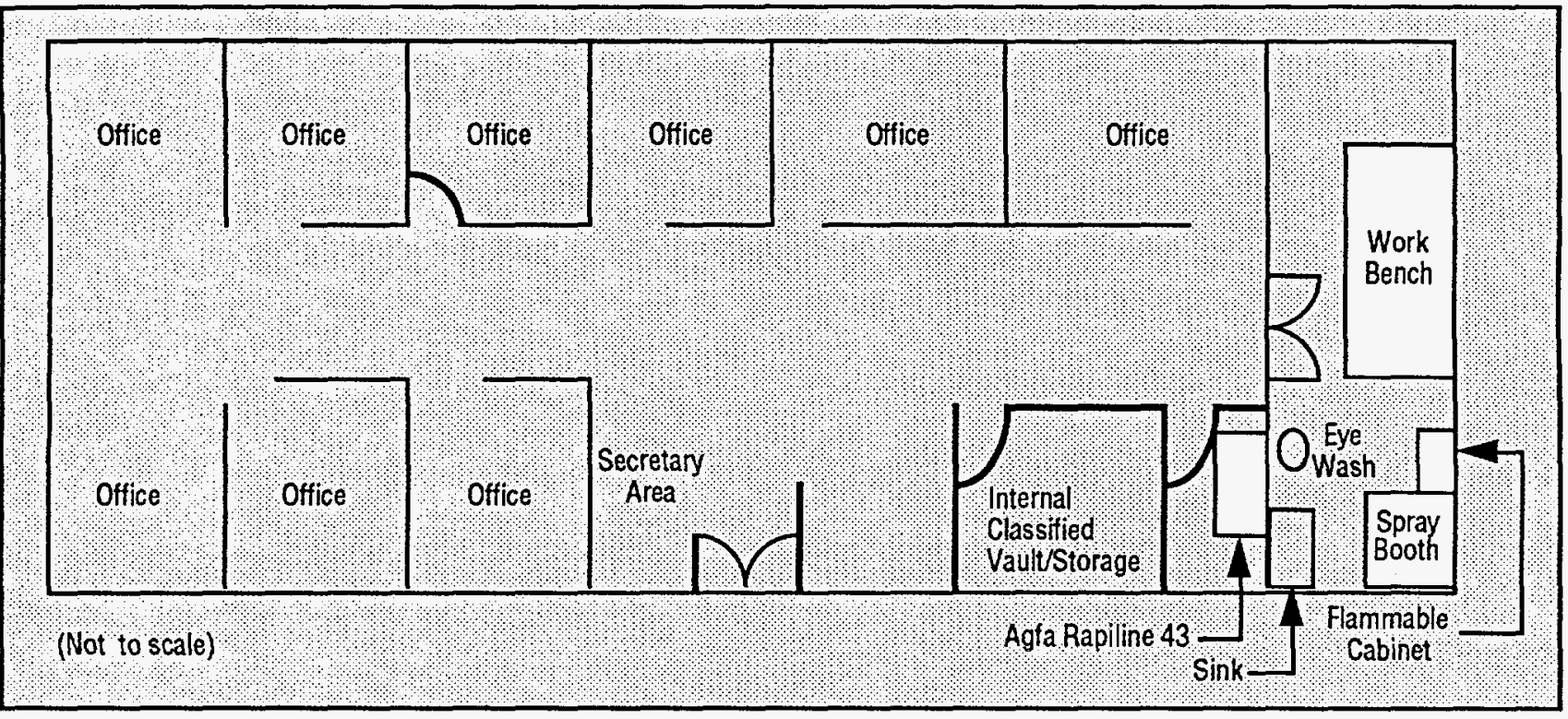

Figure 1. Technical Art Floor Plan and Equipment Layout, Bldg. 912/Rm. 138.

\section{Products}

Tech Art provides site-wide computer-generated artwork and graphics printing services.

\section{Background}

In 1992, Tech Art personnel disposed of many chemicals no longer used in their processes. Tech Art personnel also updated their chemical inventories in preparation for the Chemical Information System (CIS), which now requires bar coding on all chemicals used on site.4 As a result, the historical data on hazardous waste generation is limited to 1993 and 1994. Tech Art also has implemented new technology when feasible and substituted hazardous chemicals with nonhazardous chemicals whenever possible.

\section{Process Description}

The major hazardous waste streams generated by Tech Art are spent fixer and developer used in the processing of high-resolution negatives and paper. In 1992, Tech Art replaced the Compugraph processor with an Agfa Rapiline 43 processor. The Rapiline 43 operates at a higher temperature than the Compugraph; therefore, it uses more developer and fixer.

Tech Art personnel pay close attention to the product quality from the processor. If the processor's chemicals are spent or need to be replenished, product quality is poor. Therefore, in Fall 1994, Tech Art implemented a new maintenance procedure for the processor, based on customer demand. The chemicals generally are replaced every two weeks. However, less customer demand means less frequent maintenance or complete shut down of the processor. Although the processor is maintained by an off-site contractor, Tech Art personnel determine whether the chemicals need to be replenished or replaced. 


\section{Waste Stream Profiles}

The major waste streams (spent fixer and developer) are produced by the Agfa Rapiline 43 processor. Figure 2 is a general process flow diagram for the processor.

\section{Waste Generation}

In December 1992, Tech Art inventoried all chemicals in the area, as required by the Chemical Information System. All chemicals were evaluated for their usefulness in existing processes. Chemicals that were no longer useful were disposed of. The result was a large reduction in the amount of chemicals stored in the Tech Art area. Therefore, waste generation information is limited to 1993 and 1994.

Table 1 shows the working bath chemistry for the Agfa Rapiline 43 processor, and Table 2 shows the annual waste generation for 1993 and 1994.

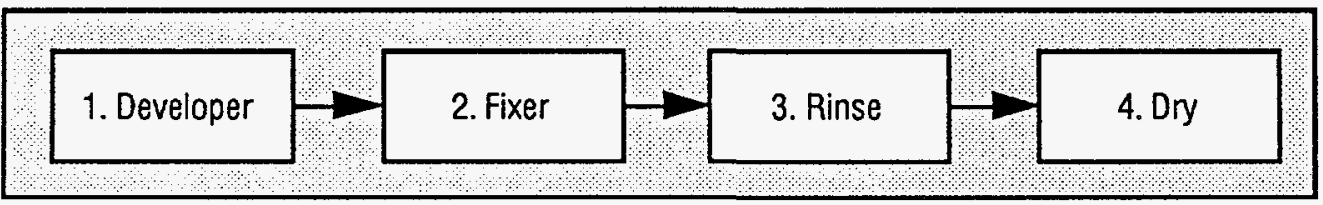

Figure 2. Process Flow Diagram of the Agfa Rapiline 43 Processor.

Table 1. Agfa Rapiline 43 Working Bath Chemistry

\begin{tabular}{|c|c|c|c|c|}
\hline Type of Bath and I.D. & $\begin{array}{l}\text { Che mical Composition of } \\
\text { Working Bath }\end{array}$ & Weight $\%$ & $\begin{array}{l}\text { Volume of } \\
\text { Bath (L) }\end{array}$ & pH \\
\hline 1. CG50 Developer 5 & $\begin{array}{l}\text { water } \\
\text { hydroxyethylethylenediamine-tricetate } \\
\text { potassium hydroxide } \\
\text { hydroquinone }\end{array}$ & $\begin{array}{c}90-95 \\
0-1 \\
1-5 \\
1-5\end{array}$ & 1 & 10.47 \\
\hline 2. CG50 Fixer ${ }^{6}$ & $\begin{array}{l}\text { water } \\
\text { ammonium thiosulfate } \\
\text { sodium sulfate } \\
\text { acetic acid }\end{array}$ & $\begin{array}{c}85-90 \\
10-15 \\
0-1 \\
0-1\end{array}$ & 1 & 5.33 \\
\hline
\end{tabular}

Table 2. Hazardous Waste Generation Summary (1993-94) ${ }^{7}$

\begin{tabular}{|r|c|c|}
\hline Waste Stream ID & $\begin{array}{c}\text { Waste ge nerated } \\
(\mathbf{k g}) \text { in 1993 }\end{array}$ & $\begin{array}{c}\text { Waste ge ne rated } \\
(\mathrm{kg}) \text { in 1994 }\end{array}$ \\
\hline FIxer & $558^{\mathrm{a}}$ & 513 \\
\hline Developer & 219 & 269 \\
\hline Filters & 3 & 11 \\
\hline Ae rosol Cans & $-\mathrm{b}$ & 9.5 \\
\hline \hline Empty Containers & 7 & 20 \\
\hline Total & 787 & $\mathbf{8 2 2 . 5}$ \\
\hline
\end{tabular}


Figure 3 shows the breakdown of the waste streams.

During 1993 and 1994, Tech Art generated approximately $800 \mathrm{~kg}$ hazardous waste annually (mainly spent fixer and developer). Spent fixer and developer were mixed from January to July of 1993; however, no documentation was available to explain the reason for combining the two waste streams. Aerosol cans comprise a small portion of the overall waste generated. These cans contain spray mount adhesive (3M), which Tech Art personnel use in the spray booth. ${ }^{8}$ Tech Art personnel change the filters in the spray booth, based on their functional appearance.

No new paints have been purchased in three or four years, and the paints that contain carcinogens that are currently stored in the Tech Art area are rarely used. When the paints have reached their expiration date, they will be disposed of properly, and Tech Art will purchase no new paints.

\section{Waste Minimization Recommendations}

No recommendations for further waste reduction can be made at this time. Almost all Tech Art processes are now done on computers. Because all excess chemicals were disposed of in 1992, very few chemicals remain in the Tech Art area. Small tubes of paint are still stored in the area, but they are seldom used. In addtion, they will be disposed of when they have reached their expiration dates, and no new paints will be purchased to replace them.

Tech Art personnel already minimize the waste generated by the Agfa Rapiline 43 processor. Although chemical use could be reduced by running the processor at a lower temperature than recommended by the manufacturer, product quality would be compromised. Tech Art personnel closely monitor processor maintainence, and decisions to replenish or replace the processor chemicals are strictly based on customer demand.

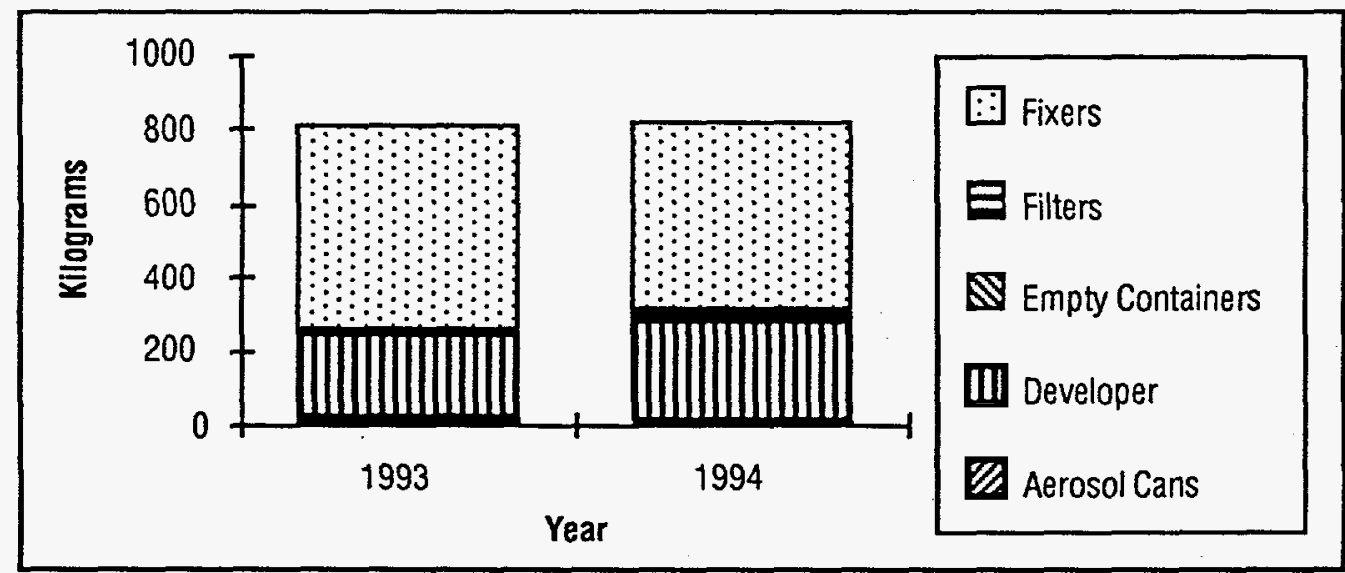

Figure 3. Waste Generation Summary (1993-94). 


\section{References}

1. U.S. Department of Energy (DOE), Order 5400.1, General Environmental Protection Program (November 9, 1988).

2. U.S. DOE, Order 5400.3, Hazardous and Radioactive Mixed Waste Program (February 22, 1989).

3. U.S. DOE, SNL/California, Pollution Prevention Opportunity Assessment Plan for SNL/CA, PD457712 Issue 3 (August 11, 1994).

4. Flores, Carol, 1995, Sandia National Laboratories Technical Communications Department, personal communication with $\mathrm{H}$. M. Torres.

5. Agfa Corporation, CG50 Developer, Material Safety Data Sheet \#138-2 (April 1988).

6. Agfa Corporation, CG50 Fixer, Material Safety Data Sheet \#139-2 (June 1989).

7. SNL/California, Waste Storage Log (1993 and 1994).

8. 3M, Scotch Spray Mount Artist Adhesive, Material Safety Data Sheet \#10-4800-8. 
UNLIMITED RELEASE

INITIAL DISTRIBUTION

U.S. Department of Energy (2)

Albuquerque Operations Office

Attn.: J. L. Arellano, KAO

J. E. Orban, WMD

P. O. Box 5400

Albuquerque, NM 87115

MS1305, R. Davis, Org. 7576

MS1305, M. Walsh, Org. 7576

MS9001, T. Hunter, Org. 8000

Attn.: E. E. Ives, 5200

J. B. Wright, 5300

M. E. John, 8100

R. J. Detry, 8200

W. J. McLean, 8300

L. A. Hiles, 8400

P. N. Smith, 8500

L. A. West, 8600

R. C. Wayne, 8700

M. T. Dyer, 8800

D. L. Crawford, 8900

MS9021, K. W. Gordon, Org. 8535

MS9021, R. H. Tucker, Org. 8535

MS9021, C. Flores, Org. 8535

MS9222, G. Faulkner, Org. 8642

MS9222, D. N. Nissen, Org. 8642

MS9222, H. J. McConnell, Org. 8642

MS9222, N. M. Phillips, Org. 8642 (15)

MS9222, S. J. Raubfogel, Org. 8642

MS9222, K. K. Shepodd, Org. 8642

MS9022, Technical Communications Department, 8535, for OSTI (10)

MS9022, Technical Communications Department, 8535/Technical Library, 13414

MS0899, Technical Library, 13414 (4)

MS9018, Central Technical Files, Org. 8523-2 (3) 